\title{
Barriers to prosperity - developing countries and the need for trade liberalisation
}

IEA Discussion Paper No. 44

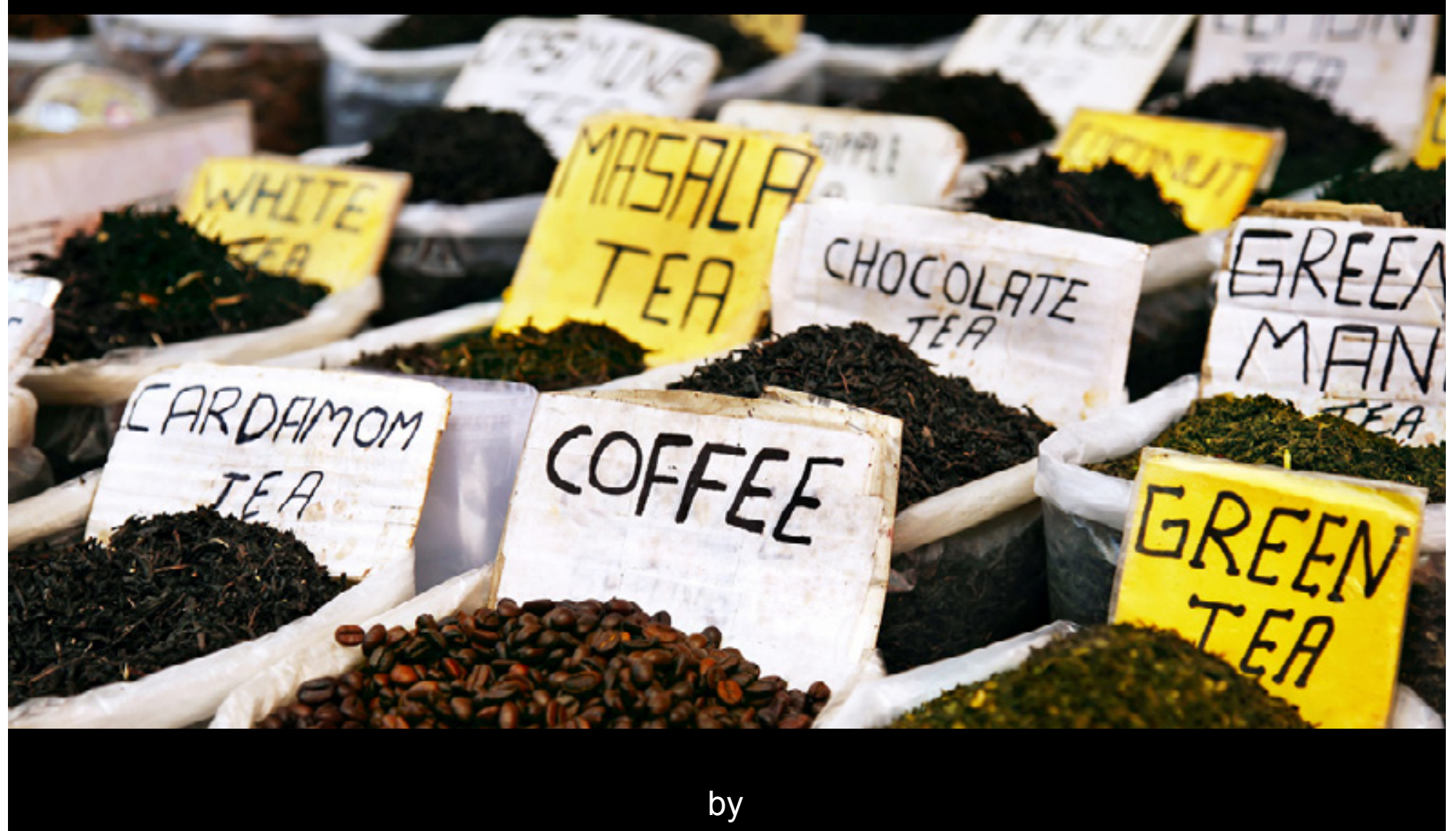

Sushil Mohan, Sangeeta Khorana and Homagni Choudhury

November 2012

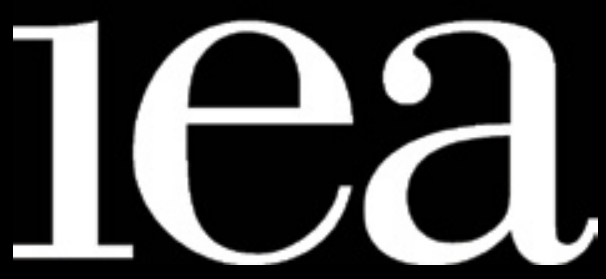




\section{Sushil Mohan", Sangeeta Khorana ${ }^{\dagger}$ and Homagni Choudhury ${ }^{\dagger}$}

\# Economic Studies, School of Business, University of Dundee, Dundee DD14HN, United Kingdom (Email: s.mohan@ dundee.ac.uk; Tel: +44 1382 384381; Fax: +44 1382384691 ).

†School of Management and Business, Aberystwyth University, Aberystwyth SY23 3DD, United Kingdom (Email: sak@ aber.ac.uk; hoc6@aber.ac.uk).

We would like to thank Anup Pujari and Vijay Laxmi Pandey from the Ministry of Commerce, Government of India for providing useful information. We are also thankful to the participants at the May 2011 Development Studies Association Scotland Conference for their helpful comments and advice. 


\section{Contents}

Introduction

Tropical Beverages: Exports and Tariffs by Processing Level

Tariff Escalation

Non-Tariff Barriers

Conclusions and policy implications

References 


\section{Executive summary}

Non-tariff barriers are an important impediment to trade for less developed countries. Such barriers can be very high on both processed and unprocessed agricultural products. These barriers include:

- EU rules of origin and rules relating to traceability.

- The combination of these rules with preferential trade agreements which becomes more onerous as the degree of processing increases.

o Health and safety regulations.

o Labelling schemes such as fair trade and organic.

o Environmental standards, such as those relating to palm oil exports.

- Both export and import procedures imposed by developing countries themselves: for example, exporting in India involves 12 separate processes.

Non-tariff barriers need to be brought to the forefront of the trade debate if developing countries are to move into the export of higher value added products.

Currently, developing countries have a low share of exports of final processed products which normally have a higher value added than primary agricultural products. For example, developing countries account for 91 per cent of raw coffee exports but only 3 per cent of processed coffee exports.

This situation is frequently blamed on developed countries applying trade barriers and escalating tariffs on processed commodities.

However, there is little truth in this allegation, at least in relation to the important commodities of coffee, tea and cocoa. However, tariffs barriers do exist in relation to other commodities such as cotton, rice and so on.

Not only are tariff barriers close to zero on coffee, tea and cocoa, there is also very little tariff escalation - that is the level of tariffs on processed products is not significantly greater than the level of tariffs on unprocessed products. Japan is the only major exception to this general pattern.

On the other hand, tariff barriers between developing countries themselves can be very high. For example, tariffs on roasted coffee are 71 per cent in Mexico and 99 per cent in India. There is, however, little evidence of tariff escalation on trade between developing 
countries: tariffs are often very high on both processed and unprocessed agricultural products.

There may well be important tariff barriers with regard to higher degrees of processing of more complex products (such as chocolate). These are especially prevalent in product lines where there is competition between developed and under-developed countries or where developed countries produce some of the ingredients for these products (for example, milk and sugar for chocolate).

Non-tariff barriers are often home grown within developing countries themselves. The experience of trade reform suggests that the benefits from their removal will mainly flow to developing countries. Non-tariff barriers must therefore be a clear priority in future trade policy and in domestic policy making in poor countries. 


\section{Introduction}

While developing countries (DCs) are the major producers of primary agricultural products in their raw or semi-processed form developing countries do not dominate export markets. Developed countries account for about two-thirds of total world agricultural exports: see Table 1.

\begin{tabular}{|c|l|l|l|l|l|}
\hline Table 1: World market shares of agricultural products in total exports \\
\hline Period & $\begin{array}{c}\text { Total world } \\
\text { agricultural } \\
\text { exports } \\
\text { (annual } \\
\text { average, } \\
\text { \$billion) }\end{array}$ & $\begin{array}{c}\text { Composition of total } \\
\text { world agricultural } \\
\text { exports (annual average, } \\
\text { \$billion) }\end{array}$ & \multicolumn{2}{|l|}{$\begin{array}{l}\text { Share in total world } \\
\text { agricultural exports (\%) }\end{array}$} \\
\hline & & $\begin{array}{l}\text { High } \\
\text { income } \\
\text { countries }\end{array}$ & $\begin{array}{l}\text { Developing } \\
\text { countries }\end{array}$ & $\begin{array}{l}\text { High } \\
\text { income } \\
\text { countries }\end{array}$ \\
\hline $\mathbf{1 9 8 0 - 8 9}$ & 238.87 & 72.58 & 166.29 & 30.4 & 69.6 \\
\hline $\mathbf{1 9 9 0 - 9 9}$ & 395.95 & 110.56 & 285.39 & 27.9 & 72.1 \\
\hline $\mathbf{2 0 0 0 - 0 9}$ & 665.65 & 220.96 & 444.68 & 33.2 & 66.8 \\
\hline
\end{tabular}

Source: Averages based on data from TradeSTAT; FAO Statistical Yearbook $(2007-08,2010)$

Notes:

1. Developing countries include 136 countries that belong to low and middle income categories as defined by the World Bank based on 2010 GNI per capita: low income is defined as $\$ 1,005$ or less; lower middle income, $\$ 1,006$ - $\$ 3,975$ and upper middle income, $\$ 3,976-\$ 12,275$.

2. High income countries include 48 countries that belong to the high income category $(\$ 12,276$ or more), of which 31 are OECD members.

An important reason for DCs low share in total world agricultural exports is their low share in world exports of agricultural processed (or final) products. Table 2 shows that agricultural processed product exports constitute 41 per cent of total world agricultural exports, of which the share of high income countries is 72 per cent. DCs primarily specialise in exports of agricultural primary products while industrial countries specialise in processed products. A question relevant from the policy perspective "is why have DCs failed to increase their exports of agricultural processed products thereby moving up the value chain?" 


\begin{tabular}{|c|c|c|c|c|c|c|}
\hline \multirow[t]{2}{*}{ Period } & \multicolumn{2}{|c|}{$\begin{array}{l}\text { Total world exports of } \\
\text { agricultural final } \\
\text { products }\end{array}$} & \multicolumn{2}{|c|}{$\begin{array}{l}\text { Composition of world } \\
\text { exports of agricultural } \\
\text { final products (\$billion) }\end{array}$} & \multicolumn{2}{|c|}{$\begin{array}{l}\text { Share in the world } \\
\text { exports of agricultura } \\
\text { final products }(\%)\end{array}$} \\
\hline & $\begin{array}{l}\text { Value } \\
\text { (\$billion) }\end{array}$ & $\begin{array}{l}\text { Share in } \\
\text { total } \\
\text { agricultural } \\
\text { exports \% }\end{array}$ & $\begin{array}{l}\text { Developing } \\
\text { countries }\end{array}$ & $\begin{array}{l}\text { High } \\
\text { income } \\
\text { countries }\end{array}$ & $\begin{array}{l}\text { Developing } \\
\text { countries }\end{array}$ & $\begin{array}{l}\text { High } \\
\text { income } \\
\text { countries }\end{array}$ \\
\hline $1990-91$ & 107.58 & 32.6 & 19.88 & 87.69 & 18.5 & 81.5 \\
\hline 2000-01 & 157.77 & 37.3 & 37.14 & 120.63 & 23.5 & 76.5 \\
\hline $2006-07$ & 333.38 & 40.8 & 92.36 & 241.02 & 27.7 & 72.3 \\
\hline
\end{tabular}

Source: Computations based on data from FAO Stat and Aksoy and $\mathrm{Ng}, 2010$

The importance of improving market access for agricultural processed exports and encouraging DCs diversification into higher value-added production has been widely discussed (Diaz-Bonilla and Reca, 2000; Daviron and Ponte, 2005; Antimiani et al. 2009). Tariff escalation has been highlighted as a market access barrier that limits the ability of DCs to expand exports of their agricultural processed products (Cobban, 1988; Rae and Josling, 2003; Elamin and Khaira, 2004). Tariff escalation involves tariff rates that increase with the degree of processing. Tariff escalation has been raised as one of the important market access issues in the WTO negotiations on agriculture. Thirteen out of the 45 country negotiating proposals submitted in the context of the WTO negotiations on agriculture, asked for a substantial reduction in tariff escalation (UNCTAD, 2003).

This pattern of protection provides high rates of effective protection for developed countries' processing sectors and inhibits the expansion of such activities in DCs. Studies show that that import demand elasticities normally increase with processing, so lowering agricultural tariffs will have relatively larger trade effects on processed than on unprocessed products (Elamin and Khaira, 2004). However, there are some that do not perceive tariff escalation as a major market access barrier and suggest that, in the context of other trade distorting measures, tariff escalation does not appear to be a general problem across a wide range of agricultural products and markets (WTO, 2003).

This paper uses a case study of coffee, tea and cocoa - three main tropical beverage agricultural products - to examine whether tariff escalation constitutes a market access barrier that thwarts the diversification efforts of DCs into higher value added agricultural processed exports. ${ }^{1}$ The paper also evaluates the non-tariff barriers faced by DC's agricultural processed exports. Our analysis shows that it is not tariff escalation but non-tariff barriers in developed countries as well as in developing

\footnotetext{
${ }^{1}$ We choose these products because they are the world's biggest trading commodities and are predominantly produced in DCs and constitute a very large share of their exports. For example, coffee is the developing world's second biggest trading commodity after petroleum, with 80 per cent of total output being exported (Russell et al., 2012).
} 
countries themselves that limit the latter's ability to diversify into agricultural processed exports.

Of course, there are many other important issues in trade policy. According to Anderson et al. (2005), 63 per cent of the global gains from the complete liberalisation of trade would arise from the liberalisation of agriculture. This is remarkable, because agriculture accounts for only about nine per cent of the global merchandise trade and four per cent of global GDP. Furthermore, most of the gains accrue to the liberalising region itself.

The paper is organised as follows: the next section presents DCs tropical beverage exports by level of processing and the tariffs that are applied to them by selected developed and developing countries; the following section examines tariff escalation in tropical beverages and discusses implications for DCs agricultural processed product exports; we then examine non-tariff barriers and how these can potentially inhibit processed exports from DCs. We then conclude with policy implications. 


\section{Tropical Beverages: Exports and Tariffs by Processing Level}

Table 3 reports developed and DCs' exports of tropical beverages by the level of processing for the year $2010 .^{2}$

\begin{tabular}{|c|c|c|c|c|c|c|}
\hline \multirow{2}{*}{$\begin{array}{l}\text { Broad } \\
\text { product } \\
\text { groups }\end{array}$} & \multirow[t]{2}{*}{$\begin{array}{c}\text { Processing } \\
\text { Level }\end{array}$} & \multicolumn{3}{|c|}{ Exports (\$billion) } & \multicolumn{2}{|c|}{$\begin{array}{c}\text { Share in world exports } \\
(\%)\end{array}$} \\
\hline & & World & $\begin{array}{l}\text { Developed } \\
\text { countries }\end{array}$ & $\begin{array}{l}\text { Developing } \\
\text { countries }\end{array}$ & $\begin{array}{l}\text { Developed } \\
\text { countries }\end{array}$ & $\begin{array}{l}\text { Developing } \\
\text { countries }\end{array}$ \\
\hline \multirow{2}{*}{ Coffee } & Not roasted & 17.38 & 1.54 & 15.84 & 8.9 & 91.2 \\
\hline & Roasted & 5.78 & 5.59 & 0.19 & 96.7 & 3.3 \\
\hline \multirow{2}{*}{ Black tea } & $\begin{array}{c}\text { In packages } \\
>3 \mathrm{~kg}\end{array}$ & 3.24 & 0.18 & 3.06 & 5.6 & 94.4 \\
\hline & $\begin{array}{c}\text { In packages } \\
<3 \mathrm{~kg}\end{array}$ & 1.58 & 0.59 & 0.99 & 37.3 & 62.7 \\
\hline \multirow{3}{*}{ Cocoa } & Beans & 10.39 & 1.16 & 9.23 & 11.2 & 88.8 \\
\hline & $\begin{array}{c}\text { Butter, fat } \\
\text { and oil }\end{array}$ & 4.41 & 2.24 & 2.17 & 50.8 & 49.2 \\
\hline & \begin{tabular}{|l|} 
Powder, no \\
added sugar
\end{tabular} & 2.85 & 1.82 & 1.03 & 63.9 & 36.1 \\
\hline
\end{tabular}

Source: Computation based on trade data obtained from Trade Map (www.trademap.org) of the International Trade Centre (ITC) as accessed on 12-11-11; ITC figures are based on COMTRADE statistics.

Notes:

1. The data aggregated are mirror and direct data.

2. For countries that do not report trade data to United Nations, ITC uses the partner country data as mirror data. Mirror data is better than no data at all but there are a number of shortcomings. They do not cover trade with other non-reporting countries and invert the reporting standards by valuing exports in cif terms and imports in fob terms. 
3. Developed countries include 39 developed market economies and Developing countries include 189 developing market economies. See Trade Map (ITC) for details.

The share of developed countries in world exports of roasted coffee is 98.6 per cent in 2010 despite the fact that almost no coffee is produced in developed countries. ${ }^{3}$ In the case of cocoa, the share of DCs in world exports of cocoa beans is 93.0 per cent, while the share in world exports of cocoa powder is about 40 per cent. Similarly, developed countries have a higher share in the world exports of processed tea. This suggests that, though DCs are the main producers of coffee, tea and cocoa in primary form, the bulk of the processing for manufacture of roasted or instant coffee, packaged tea, cocoa butter and cocoa powder is done in more developed countries. This deprives DCs of the advantages of moving up the global value chain (Diaz-Bonilla and Reca, 2000).

Table 4 reports applied simple tariff averages in selected developed and DCs for tropical beverage products at different processing (primary and processed) levels; figures in parenthesis in the table report final bound tariffs. The applied tariffs take into account tariff quotas (based on the in or out of quota tariff, depending on which one is binding), free trade areas and preferential regimes for each product. Tariffs applied on tropical beverage products are generally low or zero in all developed countries except Japan. Developed country tariffs are not the cause of low export levels from DCs in these product lines.

On the other hand, tariffs applied by DCs are generally high across all products and levels of processing. A possible explanation for very high tariffs on tea and coffee in India is the desire to try to "protect" the domestic industry in east and south India from competitive exporters such as Indonesia, Sri Lanka, Brazil and Vietnam.

${ }^{3}$ The EU is the largest re-exporter of coffee followed by the US and Japan (ICO, 2010). 


\begin{tabular}{|c|c|c|c|c|c|c|c|}
\hline \multirow{2}{*}{\begin{tabular}{|l|} 
Broad \\
product \\
group \\
Processing \\
level \\
\end{tabular}} & \multicolumn{2}{|c|}{ Coffee } & \multicolumn{2}{|c|}{ Black tea } & \multicolumn{3}{|c|}{ Cocoa } \\
\hline & Not roasted & Roasted & $\begin{array}{c}\text { In packages } \\
>3 \mathrm{~kg} \\
\end{array}$ & $\begin{array}{c}\text { In packages } \\
<3 \mathrm{~kg} \\
\end{array}$ & Beans & $\begin{array}{c}\text { Butter, fat } \\
\text { and oil }\end{array}$ & $\begin{array}{l}\text { Powder, no } \\
\text { added sugar }\end{array}$ \\
\hline \multicolumn{8}{|l|}{$\begin{array}{l}\text { Developed } \\
\text { countries }\end{array}$} \\
\hline Australia & $0(1)$ & $0(0)$ & $0(0)$ & $0(0)$ & $0(1)$ & $0(0)$ & $0(0)$ \\
\hline Canada & $0(0)$ & $0(1)$ & $0(0)$ & $0(0)$ & $0(0)$ & $0(0)$ & $2(6)$ \\
\hline$E U$ & $0(0)$ & $1(8)$ & $0(0)$ & $0(0)$ & $0(0)$ & $1(8)$ & $1(8)$ \\
\hline Japan & $0(0)$ & $8(12)$ & $5(7)$ & $10(14)$ & $0(0)$ & $0(0)$ & $8(13)$ \\
\hline US & $0(0)$ & $0(0)$ & $0(0)$ & $0(0)$ & $0(0)$ & $0.3(0.3)$ & $0(0.10)$ \\
\hline \multicolumn{8}{|l|}{$\begin{array}{l}\text { Developing } \\
\text { Countries }\end{array}$} \\
\hline Argentina & $9(35)$ & $10(35)$ & $10(35)$ & $10(35)$ & $9(35)$ & $11(35)$ & $13(35)$ \\
\hline Brazil & $10(35)$ & $9(35)$ & $10(35)$ & $10(35)$ & $9(35)$ & $11(35)$ & $13(35)$ \\
\hline China & $13(8)$ & $22(15)$ & $24(15)$ & $24(15)$ & $5(8)$ & $26(22)$ & $17(15)$ \\
\hline Colombia & $9(70)$ & $13(70)$ & $9(70)$ & $13(70)$ & $10(70)$ & $9(70)$ & $9(70)$ \\
\hline India & $97(100)$ & $97(150)$ & $99(150)$ & $99(150)$ & $29(100)$ & $30(100)$ & $29(150)$ \\
\hline Indonesia & $5(47)$ & $5(40)$ & $5(40)$ & $5(50)$ & $5(40)$ & $9(40)$ & $9(40)$ \\
\hline Iran & 13 (NA) & 22 (NA) & 30 (NA) & 50 (NA) & 17 (NA) & 17 (NA) & 28 (NA) \\
\hline Mexico & $20(36)$ & $71(72)$ & $18(25)$ & $18(25)$ & $14(37)$ & $14(37)$ & $19(37)$ \\
\hline Pakistan & $10(100)$ & $10(100)$ & $10(150)$ & $10(150)$ & $5(100)$ & $5(100)$ & $5(100)$ \\
\hline Sri Lanka & $30(50)$ & $30(50)$ & $30(50)$ & $30(50)$ & $30(50)$ & $30(50)$ & $30(50)$ \\
\hline
\end{tabular}

Source: Based on average tariff data obtained from Market Access Map (www.macmap.org) of the International Trade Centre (ITC) as accessed on 13/11/2011.

Notes:

1. Tariffs reported are ad-valorem equivalents (AVE), expressed in percentage, as defined in http://www.macmap.org/ Glossary.aspx (rounded off to the nearest whole number)

2. Figures in parenthesis represent bound tariff rates. Bound tariffs reported are from the consolidated tariff schedule of WTO and may not represent the MFN tariff. NA stands for not-available. 


\section{Tariff Escalation}

In agricultural trade, tariff escalation refers to zero or low tariff rates on primary products that increase with the degree of processing of the products such that the price of value-added imports relative to raw products increases. Tariff escalation is of particular relevance to DCs that are the main producers and exporters of agricultural products as it produces a trade bias against their agricultural processed products exports. The increases in nominal and effective duties from lower to higher stages of transformation create a discrimination against the processed exports. ${ }^{4}$

Past studies confirm the widespread incidence of tariff escalation in agricultural products both in developed and DCs. The FAO (2004) study reports that the highest incidence of tariff escalation is in meat, sugar, fruit, coffee, cocoa, skins and leather. Cernat et al. (2002) report that escalation in tariffs is a major problem for products exported mostly by DCs. Doanh and Kee (2007) compare trade barriers between Vietnam and Thailand in East Asia and report the use of cascading tariff structures and tariff escalation on agricultural processed products. ${ }^{5}$

In recognition of the widespread prevalence of tariff escalation in the post-Uruguay trade round, many negotiating proposals have called for the elimination or reduction of tariff escalation as an explicit goal within the market access pillar of the Doha Round negotiations. ${ }^{6}$ The Framework of Modalities on agriculture list detailed provisions on market access with specific mention on the problem of tariff escalation among tropical products. ${ }^{7}$ The modalities suggest that special tariff-cutting rules apply for products where tariff escalation applies. The general principle is that processed products that are subject to tariffs higher than the tariffs on the raw or intermediate forms are moved to the next higher tier that requires higher tariff cuts. If they are in the highest tier, the cut is increased by six percentage points over and above the normal tariff cut that applies to that tier. If the gap between the processed and unprocessed product is less than five percentage points, then the special tariff cutting rules are not applied (WTO, 2008).

A simple method for estimating the nominal tariff escalation (or de-escalation) is to calculate the tariff wedge (TW), which is the difference in nominal tariff between the output (processed) commodity and the input (primary) commodity, i.e.:

\footnotetext{
${ }^{4}$ For example see Balassa (1968), Golub and Finger (1979); Cobban (1988); Beghin and Akshoy (2003); Rae and Josling (2003); Elamin and Khaira (2004); Panagariya (2005); Sharma (2006); Wainio and Vanzetti (2008); Laborde and Martin (2010) among others.

${ }^{5}$ See also Laird and Yeats (1987), Safadi and Yeats (1993); OECD (1997); Burman et al. (2001); UNCTAD (2003); USDA (2001); Verkat (2001),

${ }^{6}$ Colombia, Costa Rica, Guatemala and Panama have specifically proposed that "the modalities for tropical and alternative products subject to tariff escalation should provide for deeper tariff cuts for processed and semi-processed products than for primary tropical and alternative products", specifically 10 per cent greater than the maximum reductions foreseen in the formula (see WTO, 2006).

7 The Framework to Establish Modalities in Agriculture attached to the Doha Work Programme, generally known as the July Framework Agreement or "July Package", was agreed by the WTO General Council on 1st August 2005 (see WTO, 2004).
} 
$T W=t_{p}-t_{\text {in }}$

where:

$t_{p}=$ tariff (in ad-valorem terms) imposed on processed commodity

$t_{i n}^{p}=$ tariff (in ad-valorem terms) imposed on raw commodity

A TW $>0$ denotes the existence of nominal tariff escalation. ${ }^{8}$

A limitation of the nominal tariff wedge is that it under-estimates the actual level of protection accorded to the final output. A better measure is the effective rate of protection (ERP), which is aimed at measuring the degree of protection afforded to the actual addition to the value of the product that is undertaken in the country (Greenaway and Milner, 1993). The additional tariff is then compared with the additional value added from the processing. However, although this is a better indicator for the purposes of evaluating the extent of protection, it suffers from methodological and theoretical shortcomings. The computation of ERP requires detailed data on prices and production of the many vertically linked production processes in order to calculate the value added at each stage. These are not easily available and simplifying assumptions are often made. ${ }^{9}$

An important advantage of the tariff wedge estimation is that it is straightforward and reflects the floor of the level of protection. Therefore, for the purpose of this paper, we compute the tariff wedge by making a selection of individual product pairs of coffee, tea and cocoa in order to identify nominal tariff escalation between processed and primary stages of production. Past studies have mostly used bound tariffs for determining tariff escalation. This has the advantage of providing an upperlimit measure of tariff escalation that WTO members have negotiated, but it does not reflect the actual level of tariff escalation. As such, we use applied tariffs as they are often considerably lower, particularly when tariff preferences are taken into account, and therefore they better reflect the actual level of tariff escalation.

Table 5 shows the tariff wedge between commodity pairs (one non-processed, one processed good) for selected countries. We ignore values below five percentage points on the ground that they do not imply a significant level of tariff escalation. As noted above, the WTO rule also states that if the gap between the processed and unprocessed product is less than five percentage points, then it is not treated as tariff escalation and the special tariff cutting rules are not applied.

${ }^{8} \mathrm{TW}<0$ denotes the existence of nominal tariff de-escalation and TW = 0 means tariff parity.

${ }^{9}$ See Chevassus-Lozza and Gallezot (2003); Greenaway and Milner (2003); and Choudhury (2010) pp 11-14 for a review of the limitations of the ERP measure. 


\begin{tabular}{|c|c|c|c|c|}
\hline \multirow[b]{2}{*}{ Countries } & \multirow{2}{*}{$\begin{array}{c}\text { Coffee } \\
\text { (roasted } \\
\text { and non- } \\
\text { roasted) }\end{array}$} & \multirow{2}{*}{$\begin{array}{c}\text { Black Tea } \\
\text { (packages } \\
<3 \mathrm{~kg} \text { and } \\
>3 \mathrm{~kg} \text { ) }\end{array}$} & \multicolumn{2}{|c|}{ Cocoa } \\
\hline & & & $\begin{array}{c}\text { (butter and } \\
\text { beans) }\end{array}$ & $\begin{array}{c}\text { (powder } \\
\text { and beans) }\end{array}$ \\
\hline \multicolumn{5}{|l|}{$\begin{array}{l}\text { Developed } \\
\text { Countries }\end{array}$} \\
\hline Australia & $x$ & $x$ & $x$ & $x$ \\
\hline Canada & $x$ & $x$ & $x$ & $\mathrm{x}$ \\
\hline EU & $x$ & $x$ & $x$ & $x$ \\
\hline Japan & 8 & 6 & $x$ & 8 \\
\hline US & $x$ & $\mathrm{x}$ & $\mathrm{x}$ & $x$ \\
\hline \multicolumn{5}{|c|}{$\begin{array}{l}\text { Developing } \\
\text { Countries }\end{array}$} \\
\hline Argentina & $x$ & $\mathrm{x}$ & $x$ & $x$ \\
\hline Brazil & $x$ & $x$ & $x$ & $x$ \\
\hline China & 9 & $x$ & 21 & 12 \\
\hline Colombia & $x$ & $x$ & $x$ & $x$ \\
\hline India & $x$ & $x$ & $x$ & $x$ \\
\hline Indonesia & $x$ & $x$ & $x$ & $x$ \\
\hline Iran & 9 & 20 & $x$ & 11 \\
\hline Mexico & 52 & $x$ & $x$ & 5 \\
\hline Pakistan & $x$ & $\mathrm{x}$ & $\mathrm{x}$ & $\mathrm{x}$ \\
\hline Sri Lanka & $x$ & $x$ & $x$ & $x$ \\
\hline
\end{tabular}

Source: Author's calculations based on data in Table 4.

Notes: $\mathrm{X}$ denotes nil value or value below five percentage points.

Tropical beverage products face zero or very low tariffs (Table 4). Tariff escalation (Table 5) in most developed economies, except in Japan, is also very low (or zero). These processed products also generally do not attract high trade-distorting subsidies and financial support in developed economies (Mohan, 2007a).

In contrast, we can see from Table 4 that DCs impose substantial tariffs on these products in many cases. However, Table 5 tells us that the incidence of tariff escalation is low in developing countries. This is because DCs, other than some exceptions, tend to apply the same tariffs irrespective of the level of processing. Whilst the high tariffs themselves can be harmful, it is certainly not clear from 
this analysis that tariff escalation either amongst developed countries or DCs explains the lack of movement up the value chain.

A note of caution may be in order. These tariffs relate to recent years and do not imply that there was no incidence of tariff escalation previously. For example, FAO (2003) and OECD (2003) studies show significant reduction in tariff escalation during the post-Uruguay Round, but also find evidence of tariff escalation in cocoa, coffee and tea in major importing developed economies. ${ }^{10}$

If DCs were to reduce tariffs on both non-processed and processed foods, one effect might be that those enjoying high levels of protection may, in the short run, be hit by increased competition from imports or by reduced margins. This will lead to lower consumer prices along the processing chain, which can be expected to result in increased consumption. The extent of increased consumption will depend on how sensitive the market is to price changes. As a result such a policy may eventually lead either to an increase in imports or to the protected producers being forced to lower margins and eventually become more efficient, or both. The benefit of increased consumption and competition will go to the relatively more competitive producers, wherever they might be located.

Therefore, a reduction in tariffs is likely to result in increased exports of tropical primary products from DCs as they are the only producers. However, the same cannot be said for exports of products in the processed form. The benefit of increased exports of processed products will be most likely go to the more competitive processed product exporters in developed countries or DCs.

Nevertheless, the analysis above suggests that it is inappropriate to blame tariff escalation in developed or developing countries or tariffs on primary products per se as an underlying and primary factor for low levels of processing of cocoa, coffee and tea by DCs (which are the main producers of these primary products). Insofar as substantial tariff barriers exist, they are prevalent amongst the developing countries themselves. This suggests that the predominant refrain blaming developed countries for the poverty of developing countries as a result of their trade barriers imposed by the former on the latter is not true - at least in respect of tariff barriers on some of the most important primary products.

It may, however, be non-tariff barriers that potentially limit the ability of DCs to export tropical beverages and other agricultural products in processed or semi-processed form. We now move on to look at those.

${ }^{10}$ Although a problem with most past studies is that they use bound tariffs while this study uses applied tariffs. 


\section{Non-Tariff Barriers}

While tariffs on agricultural products have been declining in the past two decades, the use of nontariff barriers in trade has increased worldwide, partially offsetting the advances brought about by lower tariffs. ${ }^{11}$ Non-tariff barriers include quantitative restrictions, subsidies, anti-dumping and countervailing duties, customs valuations, product standards and technical regulations. These are measures, different from ordinary customs tariffs, that distort trade and reduce economic welfare (Baldwin, 1970). ${ }^{12}$ Often such barriers are attributed to state activity and policy measures that typically have the potential to reduce the quantity of imports, increase the price of imports, change elasticity of demand for imports, and increase uncertainty in the implementation of tariff preferences (Deardoff and Stern, 1997; UNCTAD, 2005). Non-tariff barriers are not subject to reporting by the World Trade Organization (WTO) member countries, unlike tariffs. This means that they go unreported at the multilateral level.

Though several initiatives classify non-tariff barriers, any broad consensus on the typology is lacking at the international level (Donnelly and Manifold, 2005; OECD, 2005). The UNCTAD (1994; 2005 ; 2009) classifies non-tariff barriers according to the nature of the measure, for example whether they relate to price control, finance, automatic licensing, quantity control, monopolistic or technical measures. The WTO lists non-tariff barriers under the "market access" clauses of the WTO Agreements. These include participation in trade and restrictive practices by the government, customs and administrative entry procedures, technical barriers to trade, sanitary and phyto-sanitary (SPS) measures, specific limitations and charges on imports. ${ }^{13}$

Despite a general consensus on different types of non-tariff barriers, it is difficult to measure the degree of protectionism caused by them. There are a host of studies that employ economic models such as gravity models, price-wedge models, simulation and primary data analysis to measure the extent of trade restrictiveness of non-tariff barriers, but these suffer from limitations. ${ }^{14}$ Moreover, there is lack of reliable data on non-tariff barriers. As a result, it is not easy to quantify the coverage and extent of these barriers. This section presents the results of some of these studies, not because these provide accurate assessments of non-tariff barriers, but because they call attention to key points.

Studies find that the incidence of non-tariff barriers is higher on agriculture lines than on manufactured products. ${ }^{15}$ Andriamananjara et al (2003) estimate the welfare effects of eliminating all non-tariff barriers on footwear, wearing apparel and processed foods. They use 1997 as the base year and

\footnotetext{
${ }^{11}$ The term "non-tariff barrier" and "non-tariff measure" are often used interchangeably, the term "non-tariff barrier" is used in this paper.

12 Carrere and De Melo (2009) study finds that in most cases the underlying motives for using non-tariff barriers are to promote economic, industrial, and regional development as well as to protect specified sectors from imports or from the dumping of subsidised imports. The objectives of "technical regulations" include protection of safety, human health, animal health and life, plant health, the environment and wildlife.

${ }^{13}$ See Appendix 2 for a simple classification of the non-tariff barrier inventory.

${ }^{14}$ For example see Otsuki et. al., (2001); Kox and Lejour, (2005); Mayer and Zignago, (2005); Maskus et al., (2005); Kee et al., (2006); Silva and Tenreyro, (2006); de Frahan and Vancauteren (2006); Graffham et al. (2007); Disdier et al. (2008); Helpman et al. (2008); Yue and Beghin (2009); Bradley and Lei (2011).

${ }^{15}$ See also Bora, Kuwahara and Laird (2002); Cernat et al (2002); Dean et al (2003); ECLAC (2003); FAO (2004); Zarrilli \& Musselli (2004); Donnelly and Manifold (2005); OECD (2005), Mehta (2005); Doanh and Kee (2007).
} 
find that elimination of non-tariff barriers would have resulted in an annual increase in global welfare of almost US $\$ 2.3$ billion. ${ }^{16}$ Bora et al. (2002) find that agricultural products exporters in all countries report a high incidence of non-tariff barriers which increases production costs. The costs depend on the stringency of measures applied, their implementation, the nature of supply chain and the degree of conformity in the domestic market, which in most cases is weak in developing countries. Dean et al (2006) find non-tariff barriers such as regulations, standards and labeling lead to higher retail prices of processed food by as much as 87 per cent. ${ }^{17}$ Moreover, non-tariff barriers create potential entry barriers to foreign markets for new exporters (OECD, 2001).

Technical barriers, attributed to differences in technical standards between the exporting and importing country, are the most common type of non-tariff barrier in agricultural products. In particular, these include specific measures to regulate product characteristics, marking, labeling, packaging, testing, sanitary and phyto-sanitary measures, inspection and quarantine processes. ${ }^{18}$ Such measures particularly manifest themselves as trade barriers when standards vary between countries. The OECD (2005) report finds that tropical beverage products are notably affected by marking, labeling and packaging requirements, which make up 46 per cent of total complaints classified under technical barriers at the multilateral level. In a recent study Bradley and Lei (2011) report that between 1995 and 2009 there were 289 cases pertaining to meat, vegetable and fruit products reported as a Specific Trade Concerns (STCs) to the WTO; the STCs were mostly raised for reasons related to plant health, food safety and risk assessment.

The implementation of stringent technical requirements is attributed to risk-averse and qualityconscious consumer behaviour in developed countries. In this respect it has been argued that standards and regulations can be perceived to act as a catalyst to upgrade the production structures in the processing industries of developing countries to make them compatible with international standards (Henson, 2006). But this often does not happen as developing countries have limited capability and resources to fulfill stringent standards requirements, particularly when these require sophisticated detection and testing equipment and methods. A related problem is the requirement for internationally accredited agencies to certify standards, which increases total costs for developing country exporters. As a result, these requirements become non-tariff barriers and retard exports of processed products from developing countries. For example, in Uganda, robusta coffee is produced organically by default. Despite this, it is difficult for coffee producers in Uganda to get produce certified as organic due to the absence of locally accredited certification firms and this results in farmers missing out on premium prices (Bigirwa, 2004).

Non-tariff barriers reported on agricultural products also include measures needed to comply with EU regulation on traceability, which came into force in January 2005 , and which requires all exporters to identify the origin of products. ${ }^{19}$ This imposes an additional cost burden on developing country exporters as the domestic regulations in developing countries do not require traceability of the supply chain. Regulations on environmental and labour standards have also been reported to impact adversely on agricultural exports, particularly agricultural processed exports from developing

\footnotetext{
${ }^{16}$ This study employs the GTAP modeling approach using price data from Euromonitor and non-tariff barriers coverage information from UNCTAD for 14 product groups and 18 regions to simulate the impact of non-tariff barriers on exports, imports and the overall welfare using 1997 as the base year. ${ }^{17}$ This study uses city-level retail price data for 2001 from the EIU CityData for 47 products in 115 cities in more than 60 countries.

${ }^{18}$ Sanitary and phyto-sanitary measures are often guided by animal health and plant protection concerns in developed countries.

${ }^{19}$ Regulation EC/178/2002 (European Parliament, 2002) defines traceability as the ability to trace and follow food, feed and ingredients through all stages of production, processing and distribution. The main objective is that when a risk is identified its source can be traced in order to swiftly act on the risk. Detailed information on traceability can be found at:

http://ec.europa.eu/food/food/foodlaw/traceability/index en.htm
} 
to developed countries. ${ }^{20}$

Paradoxically, the manner in which developed countries allow tariff preferences to developing countries constitutes a form of non-tariff barrier. In the multilateral framework, the Generalised System of Preferences (GSP) scheme provide unilateral and non-reciprocal preferences which allow selected agricultural and industrial products originating in developing countries to come into developed countries at zero or reduced most-favoured-nation tariffs. ${ }^{21}$ Given that these schemes are autonomous and allowed at the discretion of the country offering the preference, studies show that most agricultural products that could benefit from preferential access do not do so in practice. ${ }^{22}$ For instance, developing countries have a total share of 27 per cent in cocoa butter imported by developed countries but only 2.3 per cent of this comes under the GSP preferences (Khorana, 2007).

A related issue is that strict rules of origin do not support exports of agricultural processed products from developing countries into markets such as the EU, US and Switzerland that should benefit from preferential tariffs. ${ }^{23}$ For primary agricultural products, the rules of origin are normally easy to establish but it is more difficult for agricultural processed products. This is because, for many agricultural processed products, developing countries find it difficult to source intermediate goods locally and therefore have problems justifying that there is sufficient local content to allow the tariff preference. The rules of origin do allow for "cumulation", but meeting the cumulation requirements do not help. ${ }^{24}$ For instance, the EU and the US allow cumulation only between specific regional groupings, so GSP beneficiary countries that are not part of the specified regional groups do not benefit from preferences. The existing rules in Switzerland need a minimum content of 50 per cent domestic input requirement and do not allow cumulation among products from developing countries. More generally, the requirement to comply with stringent rules of origin and completion of customs documentation to prove exporters' eligibility for preferences adds to the total cost, which often wipes out part or even the full preference margin and does not provide an incentive for developing countries to export under the preference schemes (Brenton and Ikezuki, 2005). An estimate of costs for the EU shows that the total costs of border formalities to determine the origin of a product amounts to at least 3 per cent of the total value of the product (Inama, 2003; Mattoo et al, 2003). For the USA, estimates show that the average compliance costs for developing countries to qualify for tariff preferences was 6.2 per cent in 2001 (Carrere and de Melo, 2004).

In recent years the agricultural food sector has witnessed a proliferation of private social labeling initiatives to promote "socially responsible" production that extend beyond organic production. Private sector bodies in the developed world such as the EurepGAP, the International Social and Environmental Accreditation and Labelling Alliance (ISEAL) and the Fairtrade Labelling Organisation (FLO) are engaged in developing codes for the design and implementation of social and environmental standards for the certification of final agricultural and other products around the globe ${ }^{25}$ The strategies, codes and auditing methods of private standards setters are often regarded by businesses in DCs as a subtle form of protectionism by developed countries. ${ }^{26}$

\footnotetext{
20 See Bhattacharya (1999); Chaturvedi and Nagpal (2002); Michalapoulos (1999); Bhattacharya and Mukhopadhaya (2002).

${ }^{21}$ The GSP scheme adopted through UNCTAD Resolution 21 (ii) states '...the objectives of the generalised, non-reciprocal, non-discriminatory system of preferences in favour of the developing countries, including special measures in favour of the least advanced among developing countries, should be: to increase export earnings; to promote their industrialization; and to accelerate their rates of economic growth.'

${ }^{22}$ See Michalopoulos (1999); Panagariya (2002); Brenton and Ikezuki (2005); Khorana (2007); Hoekman and Nicita (2011).

${ }^{23}$ See Inama (2003); Mattoo et al (2003); Candau et al (2004); Khorana (2007).

${ }^{24}$ Cumulation refers to the degree to which inputs (processes and/or materials) wholly or partly originating from one preferential trading partner are allowed to count towards satisfying rules of origin governing processes carried out in another preferential partner.

${ }^{25}$ They are advocates for voluntary standards as an effective mechanism for achieving positive social and environmental change.

${ }^{26}$ For further details see Mohan (2010).
} 
A recent study of Initiative for Public Policy Analysis (2012) reports that non-tariff barriers to trade are as much an impediment to trade than blanket prohibitions or tariffs. For example, environmental activists and industry groups are promoting sourcing policies and the application of standards designed to regulate trade in palm oil. They are campaigning for European and US markets to impose de facto trade bans on non-certified palm oil. These efforts, whatever their intention, are harmful because certification is costly. Whilst large companies may be able to accommodate the costs of auditing, independent small farmers without economies of scale are less capable of doing so. The report suggests that if certification is applied, it will make winners out of established vegetable oil producers in the West and harm small farmers in Nigeria and elsewhere in Africa by blocking them from international markets.

Non-tariff barriers may well impact on DCs' trade with each other. For example, Doanh and Kee's (2007) study on trade barriers between Vietnam and Thailand reports on the use of import licences and SPS measures by Thailand on agricultural imports from Vietnam. The OECD (2005) study highlights that customs and administrative procedures are non-tariff barriers which have an adverse effect on DCs' trade with each other.

In addition to non-tariff barriers in foreign markets, there are domestic non-tariff barriers in DCs which are not often highlighted in the literature but nonetheless impede exporting activity in the host country. ${ }^{27}$ The WTO groups domestic non-tariff barriers to trade, such as excessive customs documentation, import and export requirements, lack of co-operation among customs and other government agencies, inadequate use of information technology, information asymmetry and lack of transparency under trade facilitation issues. Extant literature finds that customs procedures and procedural delays at ports are the most common domestic non-tariff barriers followed by a host of administrative formalities and delays in various business and export registration procedures. These domestic non-tariff barriers increase transaction costs of exports which adversely affects export competitiveness.

A recent Government of India (2011) study on transaction costs for exports highlights the intensity and pervasiveness of domestic non-tariff barriers in DCs. An exporter in India needs to follow a tedious process (see Figure 1) and interact with a large number of agencies (see Figure 2) before being able to export. This, in effect, adds to the real resource cost of exporting in terms of an increase in the average number of documents and average time required for exports.

${ }^{27}$ For a discussion on domestic NTBs see Johanson and Weidersheim-Paul, 1975; Johanson and Vahlne, 1990; Daly and Kuwahara, 1998; Anderson and Wincoop, 2004; Mohan, 2007b; Kneller et al, 2008; Hoekman and Nicita, 2011 
Figure 1: Schematic map of the process that an exporter needs to follow to export from India.

\section{Illustrative view of the export process in India}

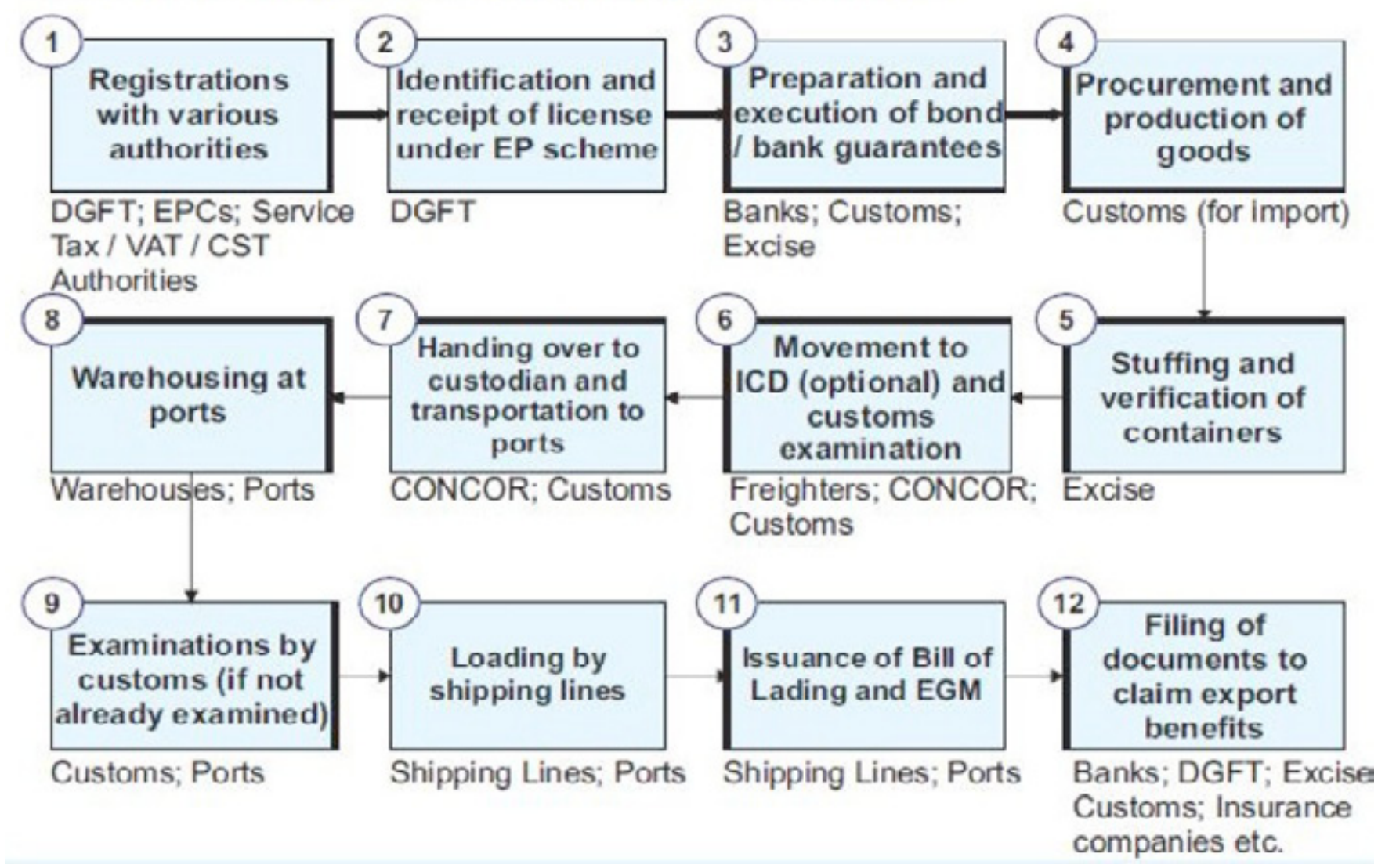

Source: Task force on transaction cost in exports - A report, Government of India (2011).

Note - the following abbreviations are used: DGFT: Director General of Foreign Trade; EPC: Export Promotion Council; VAT: Value Added Tax; CST: Central Sales Tax; CONCOR: Container Corporation of India Limited; and ICD: Inland Container Depot. 
Figure 2: Various agencies involved in the export process in India

\section{Various agencies involved in exports}

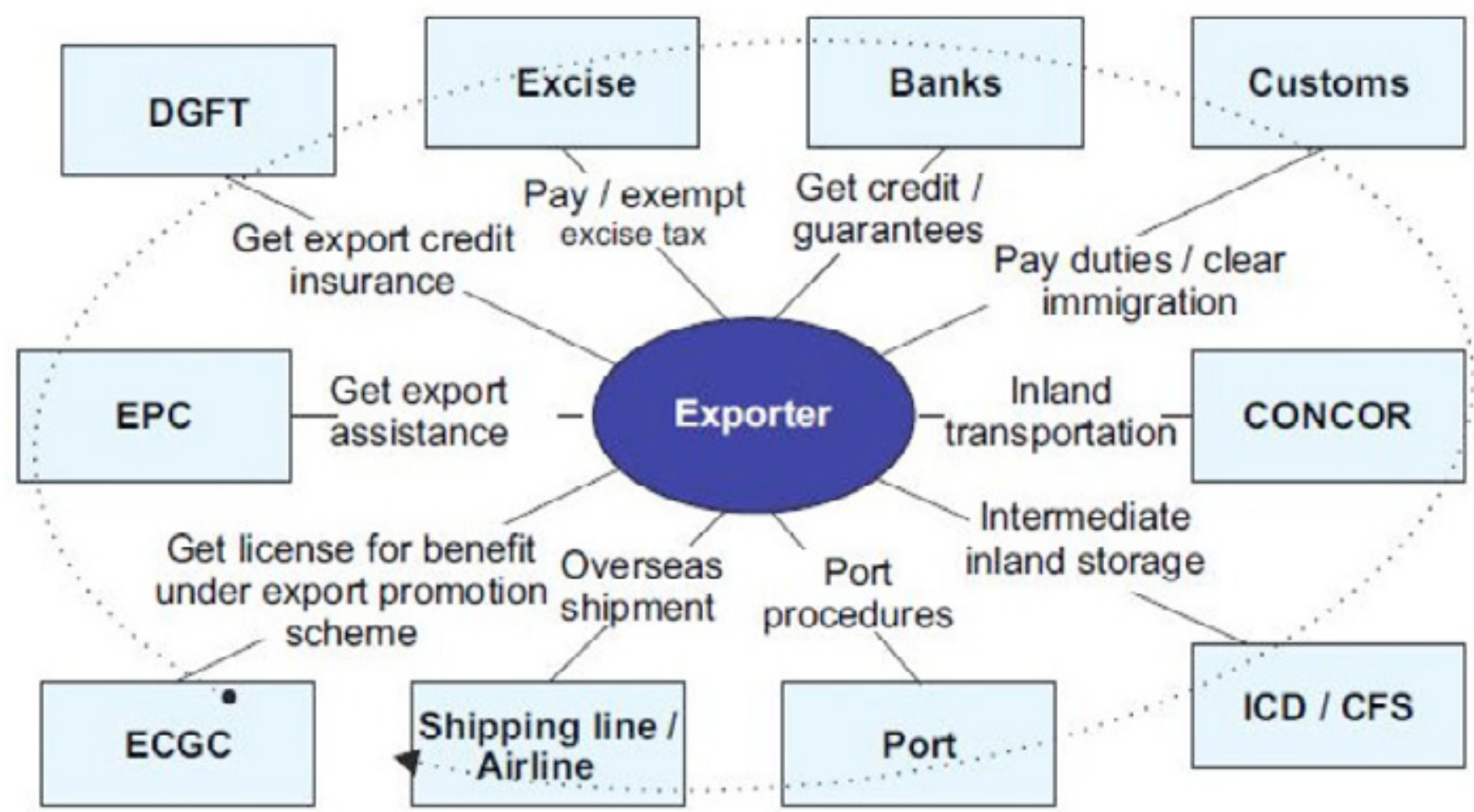

Source: Task force on transaction cost in exports - A report, Government of India (2011).

Note - the following abbreviations are used: ECGC: Export Credit Guarantee Corporation of India Limited; CFS: Container Freight Stations; also see notes in Figure 1.

The World Bank (2010) calculates the average number of documents and the average time required for exports and imports for different countries. These are shown in Table 6 . The requirement for higher numbers of documents and longer times to export for DCs relative to developed countries translates into domestic non-tariff barriers for exporters from developed countries. Furthermore, most export products have a component of imports, so ease of importing facilitates ease of exporting. Therefore, the requirement for a higher number of documents and a longer time to import for DCs relative to developed countries also translates - in effect - into domestic non-tariff barriers for DCs' exporters. As such, non-tariff barriers for imports not only affect consumers directly but also act to the detriment of export-oriented businesses in developing countries. 


\begin{tabular}{|l|c|c|c|c|}
\hline \multicolumn{2}{|l|}{ Table 6: Ease of trading across borders } \\
\hline Countries & $\begin{array}{c}\text { Documents } \\
\text { to export }\end{array}$ & $\begin{array}{c}\text { Time to } \\
\text { export }\end{array}$ & $\begin{array}{c}\text { Documents } \\
\text { to import }\end{array}$ & $\begin{array}{c}\text { Time to } \\
\text { import }\end{array}$ \\
\hline (Number) & (Days) & (Number) & (Days) \\
\hline $\begin{array}{l}\text { Developed } \\
\text { countries }\end{array}$ & & & & \\
\hline Australia & 6 & 9 & 5 & 8 \\
\hline Canada & 3 & 7 & 4 & 11 \\
\hline Japan & 4 & 10 & 5 & 11 \\
\hline UK & 4 & 7 & 4 & 6 \\
\hline US & 4 & 6 & 5 & 5 \\
\hline $\begin{array}{l}\text { Developing } \\
\text { countries }\end{array}$ & & & & \\
\hline Argentina & 9 & 13 & 7 & 16 \\
\hline Brazil & 8 & 13 & 7 & 17 \\
\hline China & 7 & 21 & 5 & 24 \\
\hline Colombia & 6 & 14 & 8 & 13 \\
\hline India & 8 & 17 & 9 & 20 \\
\hline Indonesia & 5 & 20 & 6 & 27 \\
\hline Iran & 7 & 25 & 8 & 32 \\
\hline Mexico & 5 & 12 & 4 & 12 \\
\hline Pakistan & 9 & 21 & 8 & 18 \\
\hline Sri Lanka & 8 & 21 & 6 & 19 \\
\hline $\begin{array}{l}\text { Source: Doing Business } 2011: \text { Making a difference for entrepreneurs, } \\
\text { World Bank (2010) }\end{array}$ & & & \\
\hline
\end{tabular}

The adverse effect of domestic non-tariff barriers for agricultural processed products exports from developing countries can be relatively high as DCs have to compete with developed countries in these markets. However, the effect of export barriers in the case of primary agricultural products, such as coffee, cocoa and tea, may not be as great because developing countries mostly compete for their exports with other developing countries which face more or less similar levels of domestic non-tariff barriers. 


\section{Conclusions and policy implications}

The gains from agricultural trade liberalisation are potentially enormous. As noted above, Anderson et al. (2005) estimate that 63 per cent of the global gains from the complete liberalisation of all trade would arise from the liberalisation of agriculture. Furthermore, most of the gains accrue to the liberalising region itself.

This paper looks at three forms of impediment to trade in the tea, coffee and cocoa sectors: tariffs on primary products; tariff escalation on processed products; and non-tariff barriers. We seek to explain the reasons for the poor performance of DCs in agricultural processed product exports using the case study of tropical beverages.

It is clear that tariffs and tariff escalation are not the main reasons for poor performance - especially in respect of tariffs and tariff escalation in developed countries. We then review the coverage and extent of non-tariff barriers faced by agricultural exports in developed countries. The evidence clearly points to widespread prevalence of non-tariff barriers in developed countries restricting market access for agricultural processed products from DCs. These include, for example, rules of origin and traceability requirements in the EU combined with onerous health and safety requirements. The conclusions have important policy implications in terms of the priorities of trade negotiators. It also emphasises the need for collecting reliable data on non-tariff barriers in order to quantify their coverage and problems caused by them.

The analysis also highlights that home-grown non-tariff barriers are an important trade barrier for developing countries' agricultural processed products exports. This is an area where DCs must act urgently. The benefits from lowering domestic non-tariff barriers appear to be large and their lowering could add considerably to the export potential of DCs by lowering the transaction costs of their exports. This again has important policy implications.

It should be stressed that none of the analysis suggests that non-tariff barriers are the only reason for the inability of DCs to capture a large share of agricultural processed product world exports. There are many other reasons such as intrinsic supply-side constraints in DCs which limit their ability to diversify into processed products exports. ${ }^{28}$ Nevertheless, the existence of supply-side constraints is not a justification for the prevalence of non-tariff barriers. The objective of this paper is to emphasise a neglected but important dimension of trade liberalisation, which is the need to ensure that the problem of non-tariff barriers is high on the agenda of trade negotiators and the need for developing countries' policy makers to pay more attention to addressing existing domestic non-tariff barriers.

${ }^{28}$ The supply side constraints in DCs include poor quality of physical and technical infrastructure, information bottlenecks, inadequate access to finance and relatively higher levels of corruption. 


\section{References}

Aksoy, M. A. and F. Ng (2010), 'The Evolution of Agricultural Trade Flows', Policy Research Working Paper 5308, Development Research Group (Washington, DC: World Bank).

Anderson, J.E. and E. V. Wincoop (2004), 'Trade costs', Journal of Economic Literature, 42, 3, 691751.

Anderson, K., W. Martin and D. van der Mensbrugghe (2005), 'Market and Welfare Implications of Doha Reform Scenarios', Ch. 12 in K. Anderson and W. Martin (eds.), Agricultural Trade Reform and the Doha Development Agenda, New York: Palgrave Macmillan.

Andriamananjara, S., M, Ferrantino and M. Tsigas (2003), 'Alternative Approaches in Estimating the Economic Effects of Non-Tariff Measures: Results from Newly Quantified Measures', Working Paper 03-12-C (Washington, DC: US International Trade Commission).

Antimiani, A., M. Di Maio and F. Rampa (2009), 'Tariff Protection, Tariff Escalation and African Countries: Who are the Real Friends?, Paper presented at 11th ETSG conference, 10-12 September (Rome: Italy)

Balassa, B. (1968), 'The Structure of Protection in Industrial Countries and its Effects on the Exports of Processed Goods from developing Countries', in The Kennedy Round Estimated Effects on Tariff Barriers, ed. UNCTAD, TD/6/Rev/1 (New York: United Nations).

Baldwin, R. (1970), 'Non-Tariff Distortions of International Trade' (Brookings Institution, Washington D.C.)

Beghin, J. and A. Aksoy (2003), 'Agricultural Trade and the Doha Round: Lessons from Commodity Studies', Briefing paper 03-BP 42, Centre for Agricultural and Rural Development (lowa: lowa State University)

Bhattacharyya, B. (1999), 'Non-Tariff Measures on India's Exports: An Assessment', Occasional Paper No. 16 (New Delhi: Indian Institute of Foreign Trade).

Bhattacharyya, B. and S. Mukhopadyaha (2002), 'Non-Tariff Measures on South Asia's Exports: An Assessment' (South Asian Association for Regional Cooperation, SAARC).

Bigirwa, J. (2004), ‘Equitable Trading and Coffee - Impact in Developing Countries', Paper presented 
at the International Coffee Organization Round Table on Equitable Trading and Coffee, 18 May 2004 (London: ICO)

Bora, B., A. Kuwahara, and S. Laird (2002) 'Quantification of Non-tariff Measures', Policy Issues in International Trade and Commodities Study Series No. 1, UNCTAD/ITCD/TAB/19. New York.

Bora, B., K. Aki and S. Laird (2002), 'Quantification of Non-tariff Measures', Policy Issues in International Trade and Commodities Study, Series No. 18 (Geneva: UNCTAD)

Bradley J. R. and Lei Lei (2011), 'How Important are Tariffs and Nontariff Barriers in International Markets for Fresh Fruit?', Agricultural Economics, 42, s1, 19-32.

Brenton, P and T. Ikezuki (2005), 'The Value of Trade Preferences for Africa', Trade Note No. 21. (Washington D.C.: World Bank)

Burman, C, K. Johansson, A. Karlsson, H. Loxbo, B. Norell, Y. Mattson and M. Wilhelmsson (2001), 'Tariff escalation for agricultural and fishery products', Report 2001:12 (Swedish Board for Agriculture).

Candau, F., L. Fontagné and S. Jean (2004), 'The Utilisation Rate of Preferences in the EU', 7th Global Economic Analysis Conference (Washington D.C.)

Carrere, C. and J. de Melo (2004) Are Different Rules of Origin Equally Costly: Estimates from NAFTA. CERDI Working Paper No. 200412, Centre d'Etudes et de Recherches sur le Developpment International (CERDI), Clermont-Ferrand.

Cernat, L., S. Laird and A. Turrini, (2002), 'Back to Basics: Market Access Issues in the Doha Agenda', Trade Analysis Branch (Geneva: UNCTAD).

Chaturvedi, S. and G. Nagpal (2002), 'WTO and Product Related Environmental Standards: Emerging Issues and Policy Options before India', Research and Information for the Non-aligned and other Developing Countries (New Delhi: RIS:).

Chevassus-Lozza, E., and J. Gallezot (2003), 'Preferential Agreements - Tariff escalation: What are the Consequences of the Multilateral Negotiations for the Access of Developing Countries to the European Market?', Paper presented at the International Conference on Agricultural Policy Reform and the WTO: Where Are We Heading?, June 23-26, 2003 (Capri, Italy).

Choudhury, H. (2010), 'Trade Reforms and Performance in Indian Manufacturing: An analysis of the Impact of the Trade Reforms on Aspects of Economic Performance of the Organised Manufacturing Sector', LAP Lambert Saarbrücken.

Cobban, M.A. (1988), 'Tropical Products in the Uruguay Round Negotiations', The World Economy, 
2, 2, 233-48.

Daly, M. and H. Kuwahara (1998), 'The Impact of the Uruguay Round on Tariff and Non-Tariff Barriers to Trade in the Quad', The World Economy, 21, 2, 207-34.

Daviron, B. and S. Ponte (2005), 'The Coffee Paradox: Global Markets, Commodity Trade and the Elusive Promise of Development', Zed Books, London.

De Frahan, B.H., and M. Vancauteren (2006), 'Harmonisation of Food Regulations and Trade in the Single Market: Evidence form Disaggregated Data', European Review of Agricultural Economics 33, 3, 337-60.

Dean, J., R. Feinberg, M. Ferrantino, and R. Ludema (2003), 'Estimating the tariff equivalent of NTMS', Office of Economics Working Paper No. 2003-12-B, (Washington, DC: US International Trade Commission).

Dean, J., R. Feinberg, M. Ferrantino, R. Ludema and J. Signoret (2006), 'Estimating the Price Effects of Non-Tariff Measures' (Washington, DC: US International Trade Commission).

Deardorf, A. and R. Stern (1997), 'Measurement of Non-Tariff Barriers', OECD Economics Department Working Paper No.179 (Paris: OECD).

Deb, U.K. (2007), 'Non-tariff Barriers in Agricultural Trade: Issues and Implications for Least Developed Countries', ARTNeT Policy Brief, No: 12, Asia-Pacific Research and Training Network on Trade, Bangkok (An UNESCAP Initiative)

Diaz-Bonilla, E. and L. Reca (2000), 'Trade and Agroindustrialization in Developing Countries: Trends and Policy Impacts', Agricultural Economics, 23, 3, 219-229.

Disdier, A. C., L. Fontagné, and M. Mimouni (2008), 'The Impact of Regulations on Agricultural Trade: Evidence from the SPS and TBT Agreements', American Journal of Agricultural Economics, $90,2,336-50$.

Doanh, K.N. and Y. Kee (2007), 'A Comparative Study of the Trade Barriers in Vietnam and Thailand,' International Area Review, 10, 1, 239-66.

Donnelly, W. A. and D. Manifold (2005), 'A Compilation of Reported Non-Tariff Measures: Description of the Information', Working Paper No. 2005-05-A (Washington, DC: US International Trade Commission).

ECLAC (Economic Commission for Latin America and the Caribbean) (ECLAC) (2003), 'Barriers to Latin and Caribbean Exports to the U.S. Market 2002-2003' (Washington, DC: ECLAC) 
Elamin, N and H. Khaira (2004), 'Tariff escalation in agricultural commodity markets', Commodity Market Review 2003-04 (Rome: FAO).

European Parliament (2002), Regulation (EC) No. 178/2002 of the European Parliament and of the Council of European Union, Official Journal of the European Communities, English Version, L31

FAO (2003), 'Major Constraints to Trade in Processed Agricultural Products Confronting Developing Countries', FAO support to the WTO negotiations, Factsheet For The Sixth WTO Ministerial Conference in Hong Kong (Rome: FAO).

FAO (2004), 'Repercussions of the Doha Trade Negotiation Round, Focused on the Development of Developing Countries: Basic Product and Trade Direction', (Rome: Food and Agriculture Organisation of the United Nations).

FAO Stat, www.faostat.fao.org, Food and Agricultural Organization of the United Nations

FAO Statistical Year Book (2007-08), Food and Agricultural Organization of the United Nations

FAO Statistical Year Book (2010), Food and Agricultural Organization of the United Nations

Golub, S. S. and J. M. Finger (1979), 'The processing of primary commodities: effects of developedcountry tariff escalation and developing-country export taxes', Journal of political economy, 87, 3, 559-77.

Government of India (2011), 'Task force on transaction cost in exports- A Report', Department of Commerce, Ministry of Commerce and Industry, Government of India, New Delhi

Graffham, A., E. Karehu, and J. Macgregor (2007), 'Impact of EurepGAP on Small scale Vegetable Growers in Kenya', Fresh Insights 6, Natural Resources Institute, Greenwich.

Greenaway, D. and C. Milner (1993), 'Trade and Industrial Policies in Developing Countries', Macmillan (London).

Greenaway, D. and C. Milner (2003), 'Effective protection, policy appraisal and trade policy reform', The World Economy, 26, 4, 441-56.

Helpman, E., M. Melitz, and Y. Rubinstein (2008), 'Estimating Trade Flows: Trading Partners and Trading Volumes', Quarterly Journal of Economics, 123, 2, 441-87.

Henson, S. (2006), 'The Role of Private and Public Standards in Regulating International Food Markets', Paper presented at the IATRC Summer Symposium: Food Regulation and TradeInstitutional Framework, Concepts of Analysis and Empirical Evidence, May 28-30, 2006 (Bonn: 
Germany)

Hoekman, B. and Nicita, A. (2011), 'Trade Policy, Trade Costs, and Developing Country Trade', World Development, 39, 12, 2069-79.

Initiative for Public Policy Analysis (2012) 'Trade barriers hurt small-scale farmers', Initiative for Public Policy Analysis, Lagos, Nigeria, 23 July (www.ippanigeria.org)

ICO (2010). Coffee Statistics, International Coffee Organization, London.

Inama, S. (2003), 'Quantifying the Trade Effects of Rules of Origin on Preference: The Case of GSP, AGOA and ACP preferences', The Origin of Goods (Paris: IADB, INRA, DELTA, CEPR).

Johanson, J. and F. Weidersheim-Paul (1975), ,The Internationalization of the Firm: Four Swedish Cases', Journal of Management Studies, 12, 3, 305-22.

Johanson, J. and J. Vahlne (1990), 'The Mechanism of Internationalization', International Marketing Review, 7, 4, 1-24.

Kee, H. L., A. Nicita, and M. Olarreaga (2006), 'Estimating Trade Restrictiveness Indices', Policy Research Working Paper Series 3840, The World Bank, Washington D.C.

Khorana, S. (2007), 'Do Trade Preferences Enhance Market Access for Developing Countries' Agricultural Products: Evidence from Switzerland?', Journal of World Trade, 41, 5, 1073-90

Kneller, R., M. Pisu and Z. Yu (2008), 'Overseas Trading Costs and Firm Export Performance', Canadian Journal of Economics, 41, 2, 639-69.

Kox , H., and A. Lejour (2005), 'Regulatory Heterogeneity as Obstacle for International Services Trade', CPB Discussion Paper No. 49, The Hague.

Laborde, D and W. Martin (2010), 'Formulas and flexibility in trade negotiations: sensitive agricultural products in the WTOs Doha agenda', Policy Research Working Paper 5200 (World Bank: Washington, D.C)

Laird and Yeats (1987), 'Tariff Cutting Formulas and Complications', in J. M. Finger and A. Olechowski (eds.), A Handbook for Multilateral Round Negotiations (World Bank: Washington D.C)

Market Access Map, www.macmap.org, International Trade Center.

Maskus, K., T. Otsuki, and J. S. Wilson (2005), 'The Cost of Compliance with Product Standards for Firms in Developing Countries: An Econometric Study', Policy Research Working Paper No. 3590, The World Bank. 
Mattoo, A., D. Roy and A. Subramanian (2003), 'The Africa Growth and Opportunity Act and its Rules of Origin: Generosity Undermined?', World Economy, 26, 6, 829-52.

Mayer, T., and S. Zignago (2005), 'Market Access in Global and Regional Trade', Working Papers 2005-02, CEPII research center.

Mehta, R. (2005), 'Non-tariff Barriers Affecting India's Exports', RIS Discussion Paper No: 97 , Research and Information System for the Non-Aligned and Other Developing Countries (New Delhi: RIS).

Michalopoulos, C. (1999), 'Trade Policy and Market Access Issues for DCs: Implications for the Millennium Round', mimeo (Washington DC.: World Bank).

Mohan, S. and J. Love (2007), Coffee Futures: Role in Reducing Coffee Producers' Price Risk, Journal of International Development, 16, 983-1002.

Mohan, S. (2007a), 'Reforming agricultural trade among developing countries', World Trade Review, 6, 3, 397-411.

Mohan, S. (2007b) "Market-based price-risk management for coffee producers", Development Policy Review, 25(3): 333-354.

Mohan, S. (2010), 'Fair Trade without its froth', Hobart Paper 170, Institute of Economic Affairs (London: IEA).

OECD (1997), 'The Uruguay Round Agreement on Agriculture and processed agricultural products', (Paris: OECD).

OECD (2001), 'Non-Tariff Measures on Agricultural and Food Products: The Policy Concerns of Emerging and Transition Economies', Organization for Economic Cooperation and Development (Paris: OECD).

OECD (2003), 'Agricultural Policies in OECD Countries: Monitoring and Evaluation', Organization for Economic Cooperation and Development (Paris: OECD).

OECD (2005), 'Non-Tariff Barriers of Concern to Developing Countries', Organization for Economic Cooperation and Development (Paris: OECD).

Otsuki, T., J. Wilson and M. Sewadeh (2001), 'A Race to the Top? A Case Study of Food Safety Standards and African Exports' (Washington, DC: World Bank).

Panagariya, A. (2002), 'EU preferential trade arrangements and developing countries', The World Economy, 25, 10, 1415-32. 
Panagariya, A. (2005), 'Agricultural Liberalisation and the Least Developed Countries: Six Fallacies', The World Economy, 28, 9, 1277-99.

Rae A. and T. Josling (2003), 'Processed food trade and developing countries: protection and trade liberalization', Food Policy, 28, 2, 146-66.

Russell, B., S. Mohan and A. Banerjee (2012) 'Coffee Market Liberalisation and the Implications for Producers in Brazil, Guatemala and India', The World Bank Economic Review, 26(3), 514-539.

Safadi, R. and A. Yeats (1993), 'Asian Trade Barriers against Primary and Processed Commodities', World Bank Working Paper 1174 (Washington D.C.: World Bank).

Sharma, R (2006), 'The Doha Round agricultural tariff-cutting formulae and tariff escalation', Commodities and Trade Division (Rome: FAO)

Silva, J.M.C.S., and S. Tenreyro (2006), 'The Log of Gravity', The Review of Economics and Statistics, 88, 4, 641-658.

Trade Map, www.trademap.org, International Trade Center.

UNCTAD (1994), 'Directory of Import Regimes, Part I Monitoring Import Regimes', UNCTAD/ DMS/2(PART 1)/Rev. 1, Sales No. E.94.II.D.6 (New York: United Nations).

UNCTAD (2003), 'Back to Basics: Market Access Issues in the Doha Agenda', UNCTAD/DITC/TAB/ Misc.9, (Geneva: UNCTAD).

UNCTAD (2005), 'Methodologies, Classifications, Quantification and Development Impacts of NonTariff Barriers', Note by the UNCTAD Secretariat, Trade and Development Board, TD/B/COM.1/ EM.27/2 (Geneva: UNCTAD)

UNCTAD (2009), 'Report to the Group of Eminent persons on Non-Tariff Barriers, Note by the UNCTAD Secretariat, September 2009, available on www.UNCTAD.org

USDA (2001), 'Profiles of Tariffs in Global Agricultural Markets', AER-796 (Washington, D.C.: U.S. Department of Agriculture)

Verkat, J. (2001), 'Tariff Escalation for Agricultural and Fishery Products', Report 2001: 12 (Stockholm: Swedish Board for Agriculture).

Wainio, J. and D. Vanzetti (2008), 'Tariff Escalation in the Doha Talks - Bringing the Issue to Resolution', Paper presented at the 52nd Australian Agricultural and Resource Economics Society, 5-8 February. 
World Bank (2010), 'Doing Business 2011: Making a Difference for Entrepreneurs', A co-publication of the World Bank and the International Finance Corporation, World Bank (Washington D.C.)

WTO (2003), 'World Trade Report', World Trade Organisation, p. 130, table p. 42

WTO (2004), 'Doha Work Programme', Decision adopted by the General Council on 1 August 2004 (Document No. WT/L/579), World Trade Organization, 2 August 2004.

WTO (2006), 'Proposals on modalities and implementation for the fullest liberalization of tropical and alternative products', Communication from Colombia, Costa Rica, Guatemala and Panama (Document No. TN/AG/GEN/19), Committee on Agriculture Special Session, World Trade Organization, 8 June 2006.

WTO (2008) 'Revised Draft Modalities for Agriculture', (Document No. TN/AG/W/4/Rev.4), Committee on Agriculture Special Session, World Trade Organization, 6 December, 2008.

Yue, C., and J.C. Beghin (2009), 'The Tariff Equivalent and Forgone Trade Effects of Prohibitive Technical Barriers to Trade', American Journal of Agricultural Economics, 91, 4, 930-41.

Zarrilli S. and I. Musselli (2004), 'The Sanitary and Phyto-sanitary Agreement, food safety policies and product attributes', in M. D. Ingco and J.D. Nash (eds.), Agriculture and the WTO: creating a trading system for development (Washington, D.C.: World Bank), 217-36. 


\section{Appendix 1: Product Description and HS 6-Digit Codes}

\begin{tabular}{|c|c|c|c|}
\hline $\begin{array}{c}\text { Broad } \\
\text { Product } \\
\text { Groups }\end{array}$ & Processing Level & HS-Product Description & $\begin{array}{c}\text { HS 6-Digit } \\
\text { Code }\end{array}$ \\
\hline \multirow{2}{*}{ Coffee } & Not roasted & Coffee, not roasted, not decaffeinated & -90111 \\
\cline { 2 - 4 } & Roasted & Coffee, roasted, not decaffeinated & -90121 \\
\hline \multirow{2}{*}{ Black Tea } & In packages $>3 \mathrm{~kg}$ & Black tea in packages exceeding 3 kg & -90240 \\
\cline { 2 - 4 } & In packages $<3 \mathrm{~kg}$ & Black tea in packages not exceeding 3 & -90230 \\
\hline \multirow{3}{*}{ Cocoa } & Beans & Cocoa beans & -180100 \\
\cline { 2 - 4 } & Butter, fat and oil & Cocoa butter, fat and oil & -180400 \\
\cline { 2 - 4 } & Powder, no added sugar & $\begin{array}{c}\text { Cocoa powder without added } \\
\text { sugar/sweetening matter }\end{array}$ & -180500 \\
\hline \multicolumn{2}{|l|}{ Source: Trade Map (www.trademap.org), International Trade Center } \\
\hline
\end{tabular}




\section{Appendix 2: Classification of the NTB inventory}

\begin{tabular}{|c|c|}
\hline Type of NTB & Implementation of the NTB \\
\hline $\begin{array}{l}\text { Quantitative } \\
\text { restrictions } \\
\text { and similar specific } \\
\text { limitations }\end{array}$ & $\begin{array}{l}\text { Quantitative restrictions are implemented through } \\
\text { import quotas, export quotas, licensing } \\
\text { requirements for imports and exports, voluntary } \\
\text { export restraints, prohibitions, foreign exchange } \\
\text { allocation restrictions, surrender requirements, } \\
\text { import monitoring, temporary bans aimed at } \\
\text { balancing trade, discriminatory bilateral } \\
\text { agreements, counter trade, domestic content and } \\
\text { mixing requirements, mandatory certification and } \\
\text { allocation processes for quantitative restrictions. }\end{array}$ \\
\hline $\begin{array}{l}\text { Customs procedures } \\
\text { and administrative } \\
\text { practices }\end{array}$ & $\begin{array}{l}\text { Several customs procedures and administrative } \\
\text { practices, such as customs surcharges, customs } \\
\text { valuation, minimum import prices, customs } \\
\text { classification procedures, customs clearance } \\
\text { procedures, minimum customs value, excise and } \\
\text { special customs formalities create barriers to trade. }\end{array}$ \\
\hline $\begin{array}{l}\text { Non-tariff charges } \\
\text { and } \\
\text { related policies } \\
\text { affecting } \\
\text { imports }\end{array}$ & $\begin{array}{l}\text { Imports may also be affected by various policies } \\
\text { and non-tariff charges, such as special sales taxes, } \\
\text { variable levies, border tax adjustment, value added } \\
\text { tax, anti-dumping and countervailing measures, } \\
\text { cash margin requirements and rules of origin. }\end{array}$ \\
\hline $\begin{array}{l}\text { Government } \\
\text { participation } \\
\text { in trade, restrictive } \\
\text { practices and more } \\
\text { general policies }\end{array}$ & $\begin{array}{l}\text { Governments often provide subsidies and other aids } \\
\text { and allow for State trading. In addition, there are } \\
\text { State procurement policies, tax exemptions for } \\
\text { critical imports, and single or limited number of } \\
\text { channels for imports of food and agricultural } \\
\text { products. }\end{array}$ \\
\hline $\begin{array}{l}\text { Technical barriers to } \\
\text { trade }\end{array}$ & $\begin{array}{l}\text { Governments often set standards on grounds of } \\
\text { health and sanitary regulations and quality } \\
\text { standards, safety and industrial standards and } \\
\text { regulations, packaging and labelling regulations, } \\
\text { advertising and media regulations which act as non- } \\
\text { tariff barriers to trade. }\end{array}$ \\
\hline
\end{tabular}

Source: Adapted from UNCTAD (2005) and Deb (2007) 


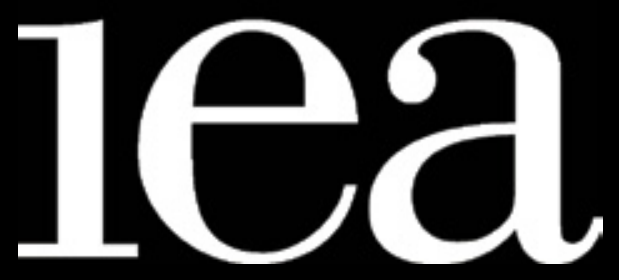

Institute of Economic Affairs

2 Lord North Street

London

SW1P 3LB

www.iea.org.uk 